Portland State University

PDXScholar

$5-25-1979$

\title{
Counseling in Allied Health Techniques of Instruction: A Career Process
}

Robert David Mills

Portland State University

Follow this and additional works at: https://pdxscholar.library.pdx.edu/open_access_etds

Part of the Counseling Commons, and the Curriculum and Instruction Commons Let us know how access to this document benefits you.

\section{Recommended Citation}

Mills, Robert David, "Counseling in Allied Health Techniques of Instruction: A Career Process" (1979). Dissertations and Theses. Paper 2769.

https://doi.org/10.15760/etd.2765

This Thesis is brought to you for free and open access. It has been accepted for inclusion in Dissertations and Theses by an authorized administrator of PDXScholar. Please contact us if we can make this document more accessible: pdxscholar@pdx.edu. 
COUNSELING IN ALLIED HEALTH

TECHNIQUES OF INSTRUCTION

A CAREER PROCESS

by
ROBERT DAVID MIIIS

B.S. 1950

Lewis and Clark College

School of Health Education
AAS 1977

Portland Community College

School of Health Occupations and Distributive Marketing Education

Presents: A Professional Paper on "Techniques of Instruction" as seen through the eyes of this writer, to Portland State University in partial fulfillment of the requirements for the degree of:

\author{
MASTER OF SCIENCE \\ in
}

EDUCATION

Portland State University 
TO THE OFFICE OF THE SCHOOL OF EDUCATION'S GRADUATE POLICIES COMMITTEE, PORTIAND STATE UNIVERSITY

The nembers of the Graduate Policies Committee approve the Professional Paper of Robert David Mills, B.S., presented Maỵ 25, 1979

signature:

Dr. William A. Olsen, Jr.

Cooperative Education 1979!

School of Counseling Education 1978.

Portland State University

signature:

Or. Howara $\mathrm{E}$. Wescott

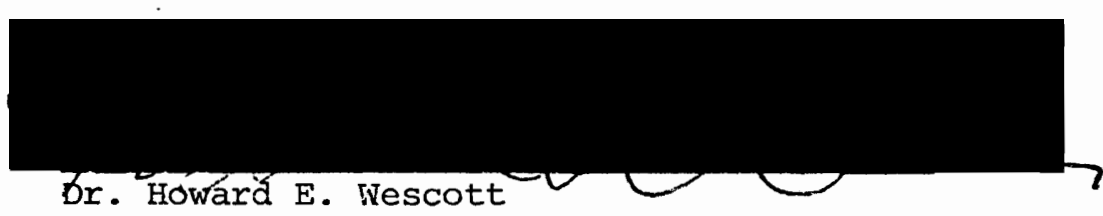

School of Health and Physical Education 1979

Portland State University

APPROVED :

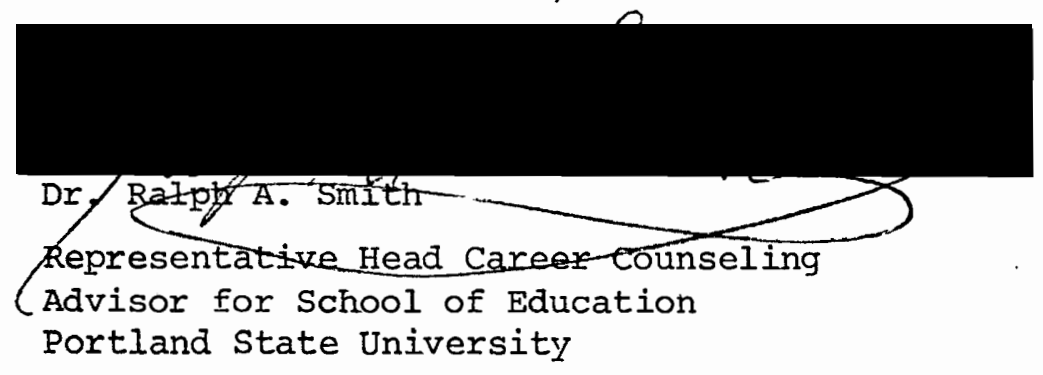


ACKNOWLEDGEMENTS

The author feels like expressing thanks to first, God, for imparted knowledge and answered prayer that has made my study a reality. Then to the Department of Defense Army/Navy Medical Service Corps for publishing Special Text NR7 (Revised) TECHNIOUES OF MILITARY INSTRUCTION, which is the baseline text which makes this paper possible.

Special thanks to Portland State University's School of Education Dean Ronald G. Petrie and my advisor Dr. Ralph A. Smith and Miss Janice Rondestvedt, Director for Health Occupation Teacher Education, and the Counseling Education Staff, and the Special Education staff for helping my studies become a reality, and finally to my family who gave me so much.

signature:

Robert D. Mills

Lieutenant Colonel Medical Service Army of the United States Retired 


\section{PREFACE}

When is a student right? Unless a student is wrong, I assume he he is always right.. One of the most critical issues for me today is trust. How can learning transfer without trust? Does plagiarism trust? I think not. Many times I take an old wheel apart (wheel meaning a curriculum course), rearrange the spokes (spokes meaning parts of a course) with the hope of sparking a thought to a person's mind for self-motivation or if nothing else, spark a new light for learning!

I'm sure I trusted in my checkerboard career and I am sure I am 'guilty of plagiarism, but it's justified if I transferred learning that could have saved a human life or made a life brighter for a person to steer a meaningful course. During my 26 plus years in the U.S. Navy and Army Medical Service, along with my newly acquired certification, (September 9, 1976) from the State of Oregon Emergency Medical Service Program as an Emergency Medical Technician (EMT) which is often called "paramedic, we learned to say "how can I help you?" I think counselors use this language all over the U.S.A. Maybe a person is falling and falls to the ground not breathing; there is only time for cardiopulmonary resuscitation (CPR). The persons starts breathing, smiles a little and says "thank you." Plagiarism, yes, I think so, but in our specialty training we surely have transfer of learning. The Pigmillion Effect ${ }^{1}$ influencing people is positive motivation for their own self-fulfilling prophecy. What's your impression? Would you like to be known as a careercounseling instructor/teacher in an allied health program?

You will have to trust to common sense and use all of someone's learning transferred to you and use whatever works to do your best in 
teaching others how to instruct. Your ship of instruction could sail into some interesting water for people to learn from for themselves. Now, since you might be interested, I would like to share a special text with you numbered 7, revised June, 1951, called Techniques of Military Instruction by the Department of Army. This is inaeed a special book for I have found nothing like it in Portland State University or the University of Oregon's Health Science Center' libraries. I hope the word "military" does not scare you! but it's okay to be scared, and if you're frightened you can learn something; you aan learn to trust yourself. in any game that might involve you or that you might be playing. This is a special book, used to teach others how to instruct in any subject that has a need for a teacher, but now I must say something more about this special publication. This publication is provided by the Army Medical Field Service School via the Armored Army School only. It reflects the current thought of this school and conforms to printed Department of Army doctrine as closely as possible. ${ }^{2}$ It describes the Army as a social system, its structures and values as "whenever two or more people, in contact with one another, become aware of one another's existence and makes predictions concerning each other's behavior, a social relationship exists," to which I subscribe my military signature.

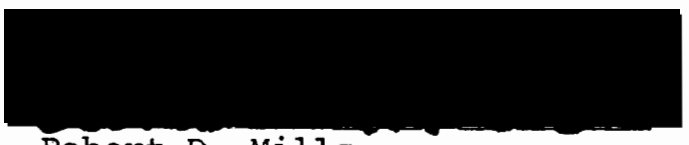

Robert D. Mills ITC-MSC, USAR Retired 
Don C. Faith ${ }^{3}$ said, in the introduction to his Army Medical Field Service School outline on Human Relations, "lectures are not premised on the theory that students are unfamiliar with the matters to be discussed." This writer's professional ethics, to the above, is for the purpose of sharing his experiences with others who might like to teach or instruct others how to instruct, and that is all. I subscribe my civil legal signature to this fact.

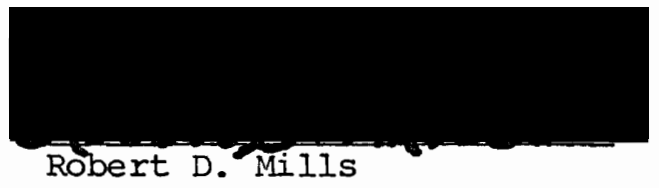

What's your impression now? Portland State University, School of :Education published a bulletin (January I, 1979) 4 about "you must possess :a valid FIRST AID CARD" and that HE 252 First Aid Course will not be equiivalent, but see the American Red Cross. Portland Community College teaches this course under HE 252, standard First Aid, ${ }^{5}$ a three hour course. Which icourse should I learn from? I would feel better about the PSU HE 252, sleep through it in one eight-hour day course for one credit hour. What 'do you feel? If you feel like one credit hour, stop here, but if you feel ilike three credit hours read on with me and I will continue saying what I have said since 1943 about instructing others to instruct any course, but we will say First Aid for now.

Yes, you can teach others to teach; this is a career. Some schools might even require specialist instructors not to teach from the seat of their pants, but take a course in "Techniques of Instruction." If instructors knew a course like this existed they might want to take the course as 
an elective for their own self-fulfillment. As an instructor/teacher you could make odes out of the following for yourself:

A servant's heart, say Phillippians-2, is becoming excited about making someone else successful. Thessalonians-2,11 says achievement is helping a person find out what he needs then helping him find the best way to get it. Leadership is seeing the consequences of our actions, says Thessalonians-5, 12-14, further in the future than those around us can. 6

What do you think? I think I can deal in plagiaristic trust with plagiarism having a positive meaning as a learning tool for each person's own way of self fulfillment. Can you?

First Perls might say to this writing:

I do my thing and you do your thing.

I am not in the world to live up to your expectations,

And you are not in this world to live up to mine.

You are you and $I$ am I,

And if by chance we find each other, It's beautiful. If not, it can't be helped. 7

And as long as people are remembered they will never die; and I will remember Neil Phelps in counseling at the Special Education Habilitation Center, Portland, Oregon, and PSU-Kiwanis Crippled Children's Camp, Mt. Hood, Oregon. 
ACKNOWLEDGMENTS

PREFACE

CHAPTER

I . INTRODUCTION

An Instructor Should Be Qualified... . . . . . . . 1

Instruction as Marketing . . . . . . . . . . . 3

II PROBLEMS OF INSTRUCTION . . . . . . . . . . . . . . 4

III INSTRUCTION . . . . . . . . . . . . . . . 6

IV SUMMARY CONCLUSIONS .. . . . . . . . . . . . . . . 24

FOOTNOTES . . . . . . . . . . . . . . . . . . 34

BIBLIOGRAPHY . . . . . . . . . . . . . . . 36

APPENDIX ....................... . . . 38 


\section{CHAPTER I}

\section{INTRODUCTION}

An Instructor Should Be Qualified

Granted I have started with a truism, but what are timing, altematives, organizing, planning, sequencing? They are part of the most critical problem in teaching other people to teach other people how to teach and maximize the transfer of learning process to the satisfaction of each person.

Who am I to pontificate instruction? I am a freestyle career writer who as a young boy played pool and missed his English lessons, and then met an unplanned career in a national general sales/manager position and as a Colonel in the Medical Service Corps of the United States Army.

I also remember when I was a young boy in a school classroom we paid respect each day to our nation's flag and the Bible was not subject to Sup̣reme Court decisions. Today it seems tradition is being swamped and drowned into a sea of memories. Can we save tradition? Possibly by takIng time to teach or learn some fundamentals of instruction, we, you and $I_{\text {, }}$ can find something we can hold on to. If the "flag" is out, and if the Bible is out, perhaps Voltaire can get this discourse started.

Men who are occupied in the restoration of health to other men, by the joint exertion of skill and humanity are above the rest of the earth.

They even partake of divinity, since to preserve and renew is almost as noble as to create. 8

I suppose if Voltaire wrote this today he would have to say "people" not men. From this last sentence I have just change my identity from a man 
to a people person. But that's okay for now we can look at some health resolutions that have no gender before we evaluate "Techniques of Instruction." Thanks to Lloyd Shearer for these "Resolutions." 9

No one will" ever get out of this world alive.

Resolve therefore to maintain a sense of values.

Take care of yourself. Good health is everyone's major source of wealth. Without it, hapoiness is almost impossible.

Resolve to be cheerful and helpful. People will repay you in kind.

Avoid angry, abrasive persons. They are generally vengeful.

Avoid zealots. They are generally humorless.

Reisolve to listen more and talk less. No one ever learns anything by talking.

Be chary of giving advice. Wise men don't need it and fools won't heed it.

Resolve to be tender with the young, compassionate with the aged, sympathetic with the striving and tolerant of the weak and the wrong.

I say, sometime in life you will have been all of these.

Please, do not equate money with success. There are many successful money-makers who are miserable human beings. What counts most is how a man achieves it.

Dr. Howard Wescott in his health counseling course, in his office, had two pesters on the wall that said, "You think you've got problems. . I shot an arrow in the air... and missed!"

Dr. William Olsen, Jr. in his counseling group theory class might respond to the above "Snoopy for President" statement by saying "Gordon would say", keep it together most of the time - with allowances - if not, look for something else.

How do you feel about instructing? Do you want to instruct? You should want to because you will have to instruct some person, some time. 
Let's together make the assumption we want to learn how to instrust, any subject, any time, any place.

\section{Instruction as Marketing}

Historically in the sales/instructor/teacher market on a marketing baseline, you have to justify your product (what you are teaching) to the other person's mind before he will buy. You have to motivate his behavior so he will want to buy what you have for sale. You owe this to your customer/student if he pays for your instruction for his own self-fulfillment.

Again, to instruct you need to do the same thing to market your specialty. On this base line you have to know your specialty before you can teach it; and, if you can teach your specialty, people will know you know your specialty, and also know you know. what you are doing, and probably buy your specialty for their own self-fulfillment. Another reason a person might buy from you is trust. Because a student trusts the transfer of information you share with him, you may produce an instructor, a satısfied student/teacher/customer.

A fact: people, human belngs, buy and sell all of their lives and that's all. Iike this example: the beginning of an Instructor's life cycle: a baby taking milk from her mother with a tear or two is "buying" and the mother is "selling" nourishment so the tears will change to sleep and then a smile.

Now fill in your own value instructor life cycle - it's up to you, the teacher, to make things happen. 


\section{PROBLEMS OF INSTRUCTION}

Does time become involved in "Techniques of Instruction?" Yes, you have controlled education time versus controlled people time and you need congruency between times for self-fulfillment. Because everything is based on time, is there really time to teach? Is there time to teach other people to teach other people how to teach? No, there is not time, but if the education system wants to continue doing business on the market place as a going concern and wants to give the student a fair profit (class information) for his investment, they must find the time for equity.

In 1974, I began listening to the people. I found through hearing and reading that "the people" are beginning to talk publicly through newspapers and magazines about instructors. It is part of the motivation for writing this paper. For example, the T.V. magazine section, Sunday Orego'nian, May 5, 1974 talks about Channel 12's Crossroads, "Teaching Teachers to Teach Law," 10 and the Army Reserve Magazine, September, 1970, talks about "Instructors Training Instructors." 11

Today, 1979, and you the reader are still with me in this discourse, let's review our assumption in Chapter I, page three, "We want to learn how to instruct." I will be talking about method and techniques of instruction next. Today, 1979, I think we can teach people how to teach people to become instructors by the infusion sysțem.

Let the infusion of "Techniques of Instruction" into the Career Education Counselor Education programmed system and into the secondary and post-secondary teacher education programmed system. The infusion system was demonstrated by 
Dr. Ralph A. Smith, P.S.U. ${ }^{12}$ Dr. Smith acted as Task Force Coordinator for the career and vocational education program for the Interinstitutional Consortium for Career Education, Salem, Oregon. This paper is attempting to use similar infusion technlques for allied health occupations.

Now let's look at instruction! 


\section{INSTRUCTION}

David W. Johnson says in his book Reaching Out, "One of the most distinctive aspects of being alive is the potential for joy, fun, excitement, caring, warmth, and personal fulfillment in your relationships with other people," and this is all available in instructorship. ${ }^{13}$.

A project assignment in Dr. W. Olsen's Interpersonal Relations ${ }^{14}$ class revealed that the books Inner Tennis (1974). The Inner Game of Tennis (1974), The Inner Gamesman (1977), with the Inner Game of Skiing (1974) and Fear of Skiing (1977) can help you keep your act together most of the time, before, during, and after instructing. Dr. Howard Wescott might say in his Health Counseling ${ }^{15}$ class, as these books say, learn to take care of yourself first and everything else will take care of itself. I say take care of your own self first, so your self is happy and you'll be a good instructor, for everything you touch will reflect how you feel, and everyone will be happy and learn in your classroom for they will feel the same way you do - happy.

Portland State University might ask you if instructing is the best career choice for you and provide you with a profile of instructor/teacher relations; something like this may be said regarding instructor/teachers:

Want to work with people;

Want to be skilled communicators;

Want to earn a respectable dollar;

Want to keep in good health, both mentally and physically;

Want to feel good about teaching;

Want to have a basic commitment with students for all to have a fulfilling life. 
Colonel Gordon A. Bohn, Army Medical Service Corps, might ask you to read The Role of Army Medical Service History, ${ }^{16}$ which addresses their education/instructor concept, which articulates with meaningful help to PSU profiles of a teacher.

Certification: The instructor rationale for certification as an instructor might read, "the certificate for instructor certification is designed to strengthen the instructor's understanding of community instruction, to relate innovation in counseling and health to people and to promote scholarship and research in instructor education."

Curriculum for instructor certification: Aaron Nildavsky $^{17}$ and William Fawcett Hill ${ }^{18}$ both talk about curriculum. Wildavsky says, "curriculum core courses are school courses and they belong to the school and not the individual instructor." We must keep this policy in mind when we start reading and evaluating Department of Defense publications. I feel it is my duty to share my copies of these publications with this paper for future community growth, by and through certified instruction. Hill says, in part, "any adequate conception of curriculum has to provide a rationale for the decision to be made before instruction can begin," and further talks about who makes the decision of which there are differing concepts. So let us use the above quote for the purpose of this paper to develop a :curriculum of instruction.

Dr. Ralph A. Smith's PSU wall picture says "Learning by Listening" and "Understanding by Reflecting" and seems to me what Ruth Falco is talking about in her publication A Handbook for Tutors and Aides. ${ }^{19}$ She talks about "The Language of Teaching"; "Teaching - Helping Someone to Behave in ways that Are New to Them": "Behavior - Things that People Do 
Whıch We Can Observe." Johari wındow arena might say to instruction do not hide part of you from other people like a facade, but look for unknown unattached resources for pure instruction, for instructor's beginning. I agree with Johari, do you?

People in the counseling health business, both non-medical and medical health practitioners deal more than less in written language style, not narrative essay style; but use a narrative technical report format style of writing. The "Army Reserve Lesson Plan Program" uses this style as does the Health Occupation Education Program of Portland State University. Maybe those who write prescriptions forced the latter style?

All medical and non-medical type people should be able to communicate in both styles of writing, but since the style of the technical report format is more dominant, let's use this style of communication.

Portland Community College "Course Content Guide" 20 articulates somewhat with "The Army Lesson Plan" and "The Lesson Plan Cutsheet" 21 and these three guides articulate with Special Text NR7 (Revised) Techniques of Military Instruction, but let's drop the word "military" out of the title for our purpose of instruction.

In this part of my discourse, my policy will be to emphasize on analysis of instruction not subject matter. I will write to you about the need for certification of instruction and hope you will agree with me in the end there is a need for certification of new instructors and statutory review courses for other instructors for the purpose of giving the student value for his self-fulfillment. And today, 1979, I think you will agree with me that it has been recognized that people must not only be trained in their varıous fields but also they must be capable of instructing others. 
This ability to pass their knowledge and skills on to other people is one of the essential qualifications of the individual community leader. It should be an individual's own desire to qualify and be certified as an instructor, and after certification, when asked, transfer the learned knowledge on to others. After experience, a person could involve himself with basic considerations and problems involved in setting up and conducting an instructor training course. What do you think?

Evaluative Analysis of Instruction: I will orient you to the "how" and "what" questions for your consideration as to the value of an instructor training course. You should be able to convert this writing and articulate it with your own style lesson plan program for your own evaluation.

1. How would you present a summary of your lesson to students at the end of each class so they can just listen to the lecture and not take notes, but could take mini-notes?

After each army lecture I would present to each student a precis. The precis would have contained a brief outline of the important points covered in the lecture that should be remembered. Example:

How could I use the preais? A precis could be used by keeping all precis in a notebook for course review before the final exam. Also after each lecture I would add my mini-notes to the precis outline to help me to complete an explanation of points which were given in the lecture.

How do you like precis in the lesson plan program?

2. How would you conduct this course for staff and student evaluation at the end of the course?

I would advise students, (1) there would be eleven hours of conference work presented to the class as one unit, (2) there would be 25 hours of 
group department instruction, (3) each. would be given the opportunity to rehearse one lesson before another student before the class presentation, and (4) a final examination of two hours would follow each student lesson. How would I use my time in this situation? Very carefully. I would advise the student class that each student grade would be based upon the following activities: (1) presentation of student lesson, (2) preparation of a lesson plan, handed in after the presentation, class mean grade of student lesson, and (4) completion of final examination. How would I use this information? Very broadly.

3. What would be your objectives for this course?

My objectives would be for this course, (1) to gain a background of understanding which will enable the person to develop and improve instructional techniques, (2) to develop certain attitudes and appreciations which will cause the person to seek improvement in his ability as an instructor, and (3) to develop skill in the use of instructional techniques.

How would I use these objectives? Very quietly.

I would advise him that his instructor training was, (1) for his own development and improvement as an instructor, (2) a basis for his supervision of instruction, (3) to improve instruction for others and mostly in his own peer group, and (4) for use by other leaders.

How would I use this advice? Very quietly and proudly.

The best conceived training plans or realistic plans depend upon good.instruction for their effectiveness. The individual instructor is the key to training other instructors for the community in which he lives. 
5. What would be the instructor's place in a community training program and what characteristics should the instructor possess?

The instructor should possess (1) knowledge of the subject, (2) instructional techniques, (3) personality, (4) leadershio, and (5) professional attitude.

How would I use this information? Like Benjamin Franklin I would review one every week and start over when the cycle was complete.

6. How could I help the instructor to improve?

I would advise the instructor for recertification by the associa'tion that (1) he could review and relearn the characteristics of a good instructor and set definite standards for himself, (2) observe other instructors, (3) he could analyze his own characteristics, building on his strengths and improve points that are not so strong, (4) concentrate on specific elements, (5) seek help of associates, and (6) make a constant effort to improve.

How would I use this information? I would use this type of course to design and assist people in the community of their traditional instructor responsibilities and duties. I would teach and I would teach others to teach others. I would maintain my specialty while teaching others and in effecting the training of others, always remembering success of programs depends upon good instruction. If our community is well-trained, the instructors must know their job.

The next four pages are in one precis describing procedures for constructing a lesson plan type test and the teacher's learning process for curriculum lesson plan test contruction, preserted in a technical report format as used in PSU Health Occupation Education Programs, for project assigrments. 
CURRICULUM

LESSON PLAN TEST CONSTRUCTION

FOR

THE TEACHER'S LEARNING PROCESS

Precis

1. PROCEDURE FOR CONSTRUCTING LESSON PLAN TESTiz.

If a test is to have the characteristics wich are desirable in a measuring device, a definite and systematic procedure should be followed in its construction.

a. Decide on the specific points or objectives that are to be measured. This is your "lesson plan" outline.

(I) These may be secured from lesson plans.

(2) Select significant subject matter.

(3) Write these points out in terms of what the student will do about them in actual application of the subject matter. NOTE: This step adds to the validity of the test. It will also provide comprehensiveness if all phases of instruction are considered.

b. Select test items which will measure the points which were listed in the outline.

c. Sequence the items for the test.

d. Write Directions. The directions should be clear and concise and specifically designed for your test.

e. Construct a key.

f. Give test to other instructors to take and criticize.

g. Make revisions and set test up in final form.

h. After test has been administered, analyze student responses and revise items.

2. POINTS TO OBSERVE IN TEST CONSTRUCTION.

a. All instructional results cannot be measured with written tests. Select the type of test which will be valid. 
b. Use application questions rather than questions that test memorization.

c. Questions should be on all levels of difficulty.

d. Avoid tri,ck or "catch" questions.

e. Use several types of questions. This gives the test variety.

f. Do not use questions which supply the answer to other questions.

g. Make each question independent of the others.

h. Avoid questions which are obvious to a person who does not know the subject.

i. Keep, method of recording answers as simple as possible.

j. Keep all of one test item on the same page.

k. Group items by types. (True-false together, cluster true-false together, etc.)

1. If correction for guessing is to be made when grading, this should be indicated in the directions.

m. A card file can be used effectively to accumulate test items.

3. TYPES OF TEST ITEMS.

Various types of test items with points to be observed in constructing each type are listed here:

a. True-False, Cluster. True-False, Modified True-False.

(1) Make approximately half of the items true and half false.

(2) Do not make one part of a statement true and the other part false.

(3.) Do not make true statements consistently longer than false statements.

(4) Avoid using such words as "all", "none", "never", in such a manner as to make them specific determiners.

(5) Where possible, make the crucial elements come near the end of the statement.

b. Multiple Choice, One Right Answer, Best Answer, Reverse Answer.

(1) Include at least four possible: responses.

(2) Include no response which is obviously wrong 
(3) Do not make correct answer consistently longer or shorter than incorrect responses.

(4) Strive for parallel construction.

c. : Matching.

(1) Include at least three extra terms from which resoonses must be chosen.

(2) Several plausible responses for each correct answer should be used:

(3) Only homogeneous material should be included in one exercise.

(4) In setting up the test, make. sure that all of the exercise appears on one page.

d. Classification. This test item is similar to the matching type. The same points should be observed in its construction.

e. Correct Order or Rearrangement.

(1) Include at least four responses.

(2) Write a special set of directions.

(3) Set up a system for scoring.

f. Completion and controlled Completion.

(I) Omit no more than three words from a statement.

(2) Place blanks near the end of the statement.

(3) Omit only key words.

(4) Do not copy statements directly from a text.

(5) It is poor practice to omit verbs.

(6) Grammatical construction should not be a key to the solution.

9. Essay.

(1) Ask for specific information.

(2) When scoring the essay-type test item:

(a) Write out answers expected.

(b) Score one item at a time on all test papers.

(c) Use code numbers or some other means to conceal student names.

h. Listing.

(1) Each thing to be listed should involve only a few words.

(2) Ask for specific facts. 
i. Identification.

(1) Make all sketches clear and accurate.

(2) Whenever possible, display the actual parts of equipment instead of using sketches.

4. REFERENCES.

You can learn more about this unit from the following sources:

loccupational Cluster Guide, OR Board Ed, Salem, OR.

Cluster Implementation Guide, Career Ed, OR State Dept. of Ed.

Occupations Cluster Program Assessment Instrument, Instructional Services

- Division, State Dept. of Ed, Salem, OR.

Evaluation Techniques; V.E. 9.001 Portland Community College, Portland, OR.

Army TM 21-250, Army Instruction

Aaron Wildavsky's new book, "Speaking Truth to Power,", title, The Art and Craft of Policy Analysis, where Aaron Wildavsky talks about curriculum, saying core courses are school courses; they belong to the school as an institution and not to the individual instructor, and says further, courses should stress not passive appreciation but active manipulation. John A. Green, Teacher-made Tests, 1963, Harper \& Row Pub, NY. 
$-16-$

THE NEXT FIVE PAGES: METHODS OF INSTRUCTION 
The next five pages are like the preceding four pages and these pages are in one precis and describe the examination stage part of methods of instruction answering the question, why give tests? Describing what the instructor has to think about when evaluating by testing. This writing is also presented in a technical report format.

How do you like technical report format writing now?

I like this style of writing for it's easy to expand or eliminate parts and is very serviceable.

I hope you like what happened so far. 
METHODS OF: INSTRUCTION

THE EXAMINATION STAGE

Precis

1. WHY GIVE TESTS?

The use of tests in the teaching learning process accomplishes these four major purposes:

a. To aid in improving instruction by

(1) discovering gaps in student learning.

(2) evaluating instructional techniques.

(3) aiding learning. Students tend to remember points covered in an examination.

b. To provide an incentive. Tests given periodically will encourage the students, as well as the instructor, to review the materials that have been presented. It must be remembered, however, that this incentive may become a superficial one.

c. To provide a basis for assigning marks.

d. To furnish a basis for selection and guidance.

2. WHAT TYPES OF TESTS DO WE USE?

a. When tests are classified according to the general purpose which they serve there could be two types:

(1) Aptitude tests. They are designed to measure general ability to learn or to profit from special types of training.

(2). Achievement tests, which are designed to measure what has been learned, achieved.

b. Tests may also be classified according to their form.

(1) Oral. Oral questions are used by the instructor in nearly every lesson to spot check the effectiveness of the instruction.

(2) Written. Written tests are of greatest value in measuring the information which students have, and other types of tests should supplement the written examination. 
(3) Performance. A performance test is a test designed to measure how well the student can perform a given piece of work. 'He is required to do something under controlled conditions while the speed and accuracy with which he performs the task are checked objectively. Merely asking a student to perform an operation and casually watching him is not a true performance test.

(4) Observation. Observation techniques are of greatest importance in learning because many phases of student achievement and behavior cannot be evaluated by the more formal types of tests. This type of evaluation is subject to several broad type of errors.

(a) The error of lenience or severity: that is, rating all individuals too high or low (frequently referred to as "personal bias" or "personal equation").

(b) The error of central tendency, or hesitation to give ratings at the extremes of a scale.

(c) The halo effect, or the general mental attitude toward or general impression of the person or object being rated.

(d) The so-called logical error which comes from presuppositions in the minds of the raters and lack of definition of the trait rated.

The instructor can improve the use of this type of evaluation through the use of check lists and observation check sheets. Samples are included in this precis.

\section{WHAT ARE THE CHARACTERISTICS OF A GOOD TEST?}

An achievement test must meet certain requirements if it is to serve as an effective measuring device in a leaming program. Although the Iactors considered below are not separate and distinct, they are defined and discussed separately in order to develop a clear understanding of the desirable features of an examination. 
a. Validity. If a test or a test item measures what it is supposed to measure, it is said to be valid. This is the most important feature of an examination. The most practical method of estimating the validity of an achievement test is to have a board of competent individuals examine the content of the test.

b. Reliability. A test is said to be reliable when it measures accurately and consistently. A highly reliable test would yield essentially the same scores when administered twice to the same students. Reliability is a term which is more meaningful to the use of standardized tests than to the instructor who uses "instructor made" achievement tests. Several factors which affect reliability of a test are of importance to the instructor.

(1). In general, the reliability of a test can be raised by increasing its length.

(2) The smaller the chances of guessing, the greater the reliability.

(3) Clear directions increase reliability.

c. Objectivity. A test is said to be objective when it can be graded in such a manner that the personal opinion of the grader is not a factor which affects the score. When personal opinion or judgement is a factor in grading, we say that the test is subjective.

d. Discrimination. When a test measures small differences in achievement it is said to discriminate. Three things will be true of a test that discriminates.

(1) There will be a fairly wide range of scores.

(2) The test will include items at all levels of difficulty.

(3) Each item will discriminate between students who are low and those who are high in achievement.

e. Comprehensiveness. The test that is comprehensive will sample liberally all phases of instruction which are supposed to be covered by the test.

f. Ease of Administration and Scoring. 
SAMPLE: OBSERVATION CHECK SHEET - - Practical Work in Emergency Medical Services Program -, Ambulance Care.

DIRECTIONS: Check the student Very Good (2 points); Satisfactory ( 1 point); or Unsatisfactory ( 0 points). Multiply the checks in the columns by the weight of the column. Add the points earned in each column to get the total points earned.

Total points Earned

\begin{tabular}{|l|l|l|l}
\hline Points Checked & (2) Very Good & (1) Satis & (0) Unsat \\
\hline 1. Work Habits & & & \\
\hline $2 . \quad$ Speed & & & \\
\hline 3. Accuracy & & & \\
\hline $4 . \quad$ Care of tools \& equipment & & & \\
\hline $5 . \quad$ Observance of safety rules & & & \\
\hline
\end{tabular}

Note: A form similar to that used by the Army Ambulance Medical Company in the observation of student lessons is also attached. 
SAMPLE PERFORMANCE TEST: This is a field situation, Wire and Time An

Ambulance Engine under alert conditions.

PART ONE (5 points) Time required to wire satisfactorily and time the engine.

Time Started

Time Completed

Time Required

SCHEDULE OF TIME AND POINTS EARNED

$\begin{array}{llll}\text { Within } 15 \mathrm{~min} . & 5 \text { points } & 25 \text { to } 30 \mathrm{~min} . & 2 \text { points } \\ 15 \text { to } 20 \mathrm{~min} . & 4 \text { points } & 30 \text { to } 35 \mathrm{~min} . & 1 \text { point } \\ 20 \text { to } 25 \mathrm{~min} . & 3 \text { points . } & \text { over } 35 \mathrm{~min} . & 0 \text { points }\end{array}$

(student to discontinue taking test if not completed within $35 \mathrm{~min}$.)

POINTS EARNED BY THE STUDENT (Encircle one) -- $\begin{array}{lllllll}5 & 4 & 3 & 2 & 1 & 0\end{array}$

PART TWO (10 points) Assistant Instructor: Check student on each point. Encircle the 1 after the item in the YES column if the answer is YES and the 0 in the NO column if the answer is No.

A. CHECK WHILE STUDENT IS TAKING THE TEST Y YES NO

1. Battery ground cable disconnected until wiring completed. . 1.0

2. Grounded battery terminal tested for spark before connecting to battery clamp. . . . . . . . . . . 10

3. Engine starts the first time . . . . . . . . . . 10

4. Student careful not to race engine ............ 1 . 0

B. CHECK AFTER STUDENT HAS COMPLETED THE TEST

5. Ammeter wired correctly . . . . . . . . . . . . 10

6. Proper wiring of distributor and spark plugs . . . . . 110

7. Generator and control unit wired correctly . . . . . 10

8. Ignition switch wired into circuit. ........... 10

9. All wrenching tools used safely and correctly . . . . . 10

.0. All wrenching tools and equipment cared for properly. . . - 10 POINTS EARNED IN PART ONE __ POINTS EARNED IN PART TWO 
$4 . \therefore$ REFERENCES.

You can learn more about this unit from the following sources:

John A. Green, Teacher-made Tests, 1963, Harper \& Row Pub, NY

Donovan Johnson \& William Green, The World of Statistics, John Murray, ...Pub, London

Carol H. Weiss, Evaluation Research, Prentice-Hall Pub, NJ

Army Instruction, TM 21-250

Oregon Emergency Medical Technician Program 


\section{CHAPTER IV}

\section{SUMMARY CONCLUSIONS}

\section{A Planned Precis Lesson Plan Program}

I am enclosing in the next pages a solution for good instruction used by the Army Medical Corp for your information and guidance to your own lesson plan type instruction.

There is no paraphrasing and the next pages are copies of the Army Lesson Planning Program. This is an historical documènt.

"Training Memorandum 2", dated 18 April, 1960 identifies and establishes the charged authority for the Army Precis Lesson Plan Program. I have seen this program: I believe this program would be good to plagiarize. I know the Army Medical Field Service School will advise by writing to:

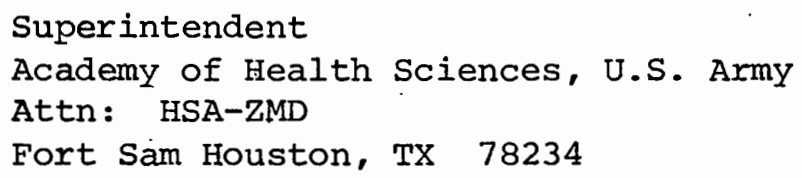

for (1) free VIDEOTAPE PROGRAMS in paramedical fields, and (2) other information on (a) catalogs, and (b) programs. I hope this information will be valuable to your community instruction group.

"Lesson Plan." First Aid, today, in 1979, is a statutory requirement for education and industries people. I wonder how many people know about this "Techniques of Instruction" system? Maybe it has been swallowed up like tradition, but I see and hear parts of this program once in a while from instructors in my age group level. Maybe they, too, began instructing in World War II. I think its time to take "Techniques of Instruction" off 
the shelf, blow off the time dust and let it breathe once again for instructor information, for the good of the community.

"Last Page.", This is a.blank lesson plan. I close this part of my guided fantasy trip in precis lesson plan instruction and thanks for joining me. I hope I have given you a reason to think about good instruction. I hope you will join me in this last blank page and re-open a new, good instruction system. 
HEADOQUARTERS

THE ADJUTANT GENERAL'S SCHOOL, U. S. ARMY

Fort Benjamin Harrison

Indianapolis 16, Indiana

TRAINING MEMORANDUM

NUMBER

Effective until 30 April 1961 unless sooner rescinded or superseded.

LESSON PLAN PROGRAM

CONTENTS

SECTION I- GENERAL

Purpose

Definitions

objectives

Operation \& Supervision

General

\section{Paragraph Page}

i 1

$\frac{1}{2} \quad 1$

$3 \cdot 2$

42

52

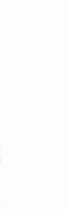

SECTION II--RESIDENT LESSON PLANS

Preparation

Revision

Distribution

Review
64

$7 \quad 6$

8.6

96

SECTION III--MASTER IESSON PLANS

Preparation

Revision

Distribution

Review
10

11

12

13 (2)

(n)

6 
b. Resident lesson plan. An expanded outline for a 50-minute or longer presentation to support resident instruction prescribed in a current program of instruction (POI). This outline is prepared and approved as prescribed herein.

c. Master lesson plan. Instructional material in complete manuscript form to support the Adjutant General officer Career (Advanced) Course for resident, USAR School, and extension course students and the interchange program. Master lesson plans may be used in other resident courses as authorized. This material is prepared and approved as prescribed herein..

3. Objectives. The objectives of the lesson plan program are as follows :

a. To provide standard guides for organization and presentation of leșson material.

b. To develop, for use of new or substitute resident instructors, comprehensive lesson plans which.will reduce the impact of instructor changes and absences.

c. To permit supervisory review of material used in TAGSUSA training to insure adequate subject coverage, employment of current doctrine, and use of meaningfụl presentation techniques to facilitate student learning.

d. To make TAGSUSA lesson plans usable for interchange with other schools and training agencies.

e. To insure that current TAGSUSA lesson materials are available for distribution to branch schools in event of mobilization.

4. Operation and Supervision.

a. The Director of Training will supervise the lesson plan program to insure attainment of objectives.

b. Directors of departments will insure that personnel of their respective departments are familiar with the provisions of this memorandum and will insure compliance by individual instructors and instructorwriters.

5. General.

a. Each hour of academic instruction relating to Adjutant General Corps subjects presented to resident students at this school and in USAR Schools will be supported by a lesson plan prepared in accordance with the provisions of this memorandum: 


\section{RESEARCH AND EVALUATION DIVISION \\ THE ARMORED SCHOOL \\ Fort Knox, Kentucky}

\section{LESSON PLAN}

INSTRUCTIONAL UNIT: Principles of First Aid.

TYPE : : Conference.

TIME ALLOTTED: One period.

CLASS PRESENTED TO: Trainees.

TOOLS, EQUIPMENT, AND MATERIALS: Three first aid dressing packets; three pistol belts; one raincoat; one bayonet scabbard.

PERSONNEL: One instructor and one assistant.

INSTRUCTIONAL AIDS: GTA 8-1; first aid packet; materials for tourniquet. REFERENCES : FM 21-11.

STUDY ASSIGNMENT: FM 21-11, pp 1-12.

STUDENT UNIFORM AND EQUIPMENT: Uniform S; notebook and pencil.

TROOP REQUIREMENTS: None.

TRANSPORTATION REQUIREMENTS: None.

NOTE: This is the first unit in the soldier's training in military first aid and sanitation. Every effort should be made to make it interesting to the soldier because the effectiveness of other units in this. subject will depend upon the way this unit is presented.

1. PRESENTATION. a. Introduction.

(I) : Reasons.

(a) In World War II approximately one man out of every 15 was wounded. Only about one man in 50 was killed but that figure could have been higher had our soldiers not known how to care for themselves and their buddies when they were wounded. 
(b) To bring the importance of a knowledge of first aid closer to you: Two of your men in this class may be injured in automobile accidents this year, and if you do not receive proper care at the scene of the accident you may become one of the more than 30,000 who are killed in automobile accidents each year.

"Do you know how to care for an injured person?"

(2) Objective: and Standards. In this lesson we will

learn a few simple rules which will guide your actions when someone is injured. The three lifesavers of first aid will be stressed.

b. Explanation.

(1) What is first aid? First aid is the care given casualties before regular medical treatment can be administered by trained individuals.

(a) Remember that aid-men cannot be with you at all times either in the Army or in off-duty activities.

(b) It is often necessary for you to administer to your buddy or some other person.

(c) You must remember that you can give first aid to yourself. "Self-aid" is necessary in combat because the soldier's primary job is fighting. There are times when your buddies will be unable to stop fighting to help you.

(2) Principles of first aid.

(a) Remain calm.

(b) Think before you act.

(c) Send for a medical officer.

(d) See what is wrong.

(e) Give first aid - the 3 lifesavers. (FM 21-11, pp 4,5$)$

NOTE: Make a chart using these points. Strips used on the Venetian blind will help in presentation of these points.

(f) Do not try to do too much.

QUESTION: What are some of the things which are done in trying to help the injured that often cause more harm than good? 
(3) Lifesaver I - STOP BLEEDING.

(a) Apply pressure first.

1. Use wounded man's first aid dressing.

QUESTION: Why do you use the wounded man's dressing instead of your own?

2. Wrap bandage around part and press down on bandage.

NOTE: See FM 21-11, pp 6 and 7.

(b) Elevate wounded arm or leg if possible.

(c) Apply tourniquet when other methods have failed to stop bleeding.

1. Place tourniquet above the wound.

2. Protect skin by putting tourniquet over clothing when possible.

3. Do not remove tourniquet until medical officer has attended to the man.

4. After two hours, if no medical officer is available, loosen the tourniquet. Tighten again if blood flows. Do not remove tourniquet.

NOTE: Use an assistant to demonstrate how to use a tourniquet. See FM 21-11, pp 8 and 9.

(4) Lifesaver II - PROTECT THE WOUND.

See FM 21-11 and GTA 8-1.

(5) Lifesaver III - PREVENT SHOCK.

(a) Treat every man for shock before he has a chance to go into shock.

NOTE: See FM 21-11, pp 12-13.

(b) Shock can cause death.

(c) To prevent or treat shock.

1. Make soldier comfortable

2. Keep head low.

3. Keep soldier warm.

4. Face down - if unconscious

5. Morphine will help prevent shock: NOTE: See FM 21-11, pp 30-31. 
2. APPLICATION. This exercise will make use of an assistant who will act the part of an injured soldier, and two members of the class who came upon the scene of the accident. The other members of the class will look for errors and make a note of any observed.

a. Situation. "You two soldiers are in an outpost about 800 yards from your company CP. A wounded man drags himself into your area. This man is critically injured. On his body are red marks - these marks indicate areas where the soldier is bleeding. You are to take such action as you would in case this were a real situation. Are there any questions? I want the rest of you men in the class to take notes on the mistakes observed. We will discuss the actions taken later."

b. The men should take the following action:

(1) Look the situation over - then one should go for medical assistance.

(2) The men remaining at the scene should stop the bleeding first.

(3) Then he should protect the wound.

(4) Treat for shock.

3. DISCUSSION AND CRITIQUE.

a. Discuss the questions brought up in the application stage.

b. Clear up any questions on the lesson.

c. Summarize the lesson.

(I) What is first aid?

(2) Principles of First Aid.

(3) Three lifesavers.

a. Close with this statement:

"Remember these few simple steps you have learned here today; they will save lives. And also remember that you can often do these things for yourself. When a man is injured, don't try to do too much but do something - and know how to do the right thing." 
Instructor

Organization

Date presented

\section{LESSON PLAN}

LESSON TITLE:

TYPE :

TIME ALLOTTED:

CLASSES PRESENTED TO:

MATERIALS FOR STUDENT USE:

INSTRUCTOR PERSONNEL:

INSTRUCTIONAL TRAINING AIDS:

REFERENCES :

STUDY ASSIGNMENTS:

STUDENT UNIFORM AND EQUIPMENT:

TROOP REQUIREMENTS:

TRANSPORTATION REQUIREMENTS

(On additional sheets, make a complete outline covering material to be presented and method by which this will be done. The following basic, skeleton outline may be used as a guide, remembering that the bulk of the material will fall under 1.b. and that under certain circumstances, sections of the outline may be omitted entirely.)

1. Presentation

a. Introduction.

(1) Opening statement

(2) Objective of lesson

(3) Reasons and/or standards

b. Explanation and/or Demonstration

2. Application by class (if to be used in lesson)

3. Examination (if to be used in lesson)

4. Discussion of critique

a. Questions from class to be cleared up

b. Summary of entire lesson

c. Closing statement 
$\underline{F} \underline{O} \underline{\mathrm{T}} \underline{\mathrm{N}} \underline{\mathrm{T}} \underline{\mathrm{S}}$ 


\section{FOOTNOTES}

\section{Preface}

I Biehler, Psychology Applied To Teaching, Second Edition. 1974.

2 Army Medical Field Service School Precis Lesson Plan, IM 54-240-20D, (U.S. Army; 1963).

3 Don C. Faith, Iecture, Army Management School Precis on Human Relations. (Washington, D.C.: George Washington University)

4 Bulletin, First Aid Requirements Effective January 1, 1979. (Portland: PSU, School of Education mimeograph)

${ }^{5}$ Course Outline, HE 252 Standard First Aid, Spring, 1979 (Portland Community College)

The Living Bible (paraphrase). (London: House Publisher Ltd, 1973)

${ }^{7}$ Professor Neil Phelps, Lecture, Counseling Class, Spring 1978 (Portland, OR: Portland State University)

Chapter I

8 Volțaire, Book from Habilitation Center Library, Portland, Oregon

9. Lloyd Shearer, The Oregonian (Portland, OR: Gannett Publishers, 1975) exact date not available

Chapter II

10"Teaching Teachers to Teach Law" segment of Columbia Crossroads program discussed in T.V. Magazine, The Sunday Oregonian (Portland, OR: Gannett Publishers, May. 5, 1974)

11. Instructors Train Instructors", The Army Reserve Magazine, September, 1970 ; p. 13

$12 \mathrm{Dr}$. Ralph A. Smith, "Statewide Infusion of Career Education into the Preparation of Teacher, Counselor, and Administration", paper prepared for Interinstitutional Consortium for Career Education, Salem, OR, September, 1976. 


\section{CHAPTER III}

13 David W. Johnson, Reaching Out

14 William Olsen, Jr., Interpersonal Relations class, Winter 1978, (Portland, OR: Portland State University)

15 Howard Wescott, Health Counselling class, Fall 1978, (Portland, OR: Portland State University)

${ }^{16}$ Colonel Gordon A. Bohn, "The Role of Army Medical Service History," (Army Pamphlet 20-200)

\section{Aaron Wildavsky, Art and Craft of Policy Analysis}

${ }^{18}$ William Fawcett Hill, Learning Through Discussion (Beverly Hills, CA: - Sage Books, . 1977).

${ }^{19}$ Ruth Falco, A Handbook for Tutors and Aids (Portland, OR: Multnomah County Intermediate Education District Program for Developing Mentally Disabled, not dated)

${ }^{20}$ Course Content Guide, from course taught by Mrs. Gwen Danielson at Portland Community College, 1973.

${ }^{21}$ United states Army, 1951. 


\section{BIBLIOGRAPHY}

hler, Psychology Applied to Teaching, Second Edition (Publisher unknown) 1974.

renbach, Carl Donald Colonel, Thesis: A Study of Two Hundred Two Drop-outs From Seven Clinical Specialist Courses of the United States Army. 1968.

loway, T. Fear of Skiing, (Publisher unknown), 1977.

loway, T. Inner Gamesman, (Publisher unknown), 1977.

loway, T: The Inner Game of Tennis, (Publisher unknown), 1974

Lloway, T. The Inner Game of Skiing, (Publisher unknown), 1974

sen, John A. Teacher Made Tests (New York, NY: Harper and Row, 1963)

Inson, David w. Reaching Out, (Publisher unknown), 1979

1. William Fawcett, Learning Through Discussion chapter in Guide for Leaders and Members of Discussion Groups, (Publisher unknown), 1977

inson, Donovan A. and William H. Green, The World of Statistics (London: John Murray)

Iung, Kristie Rice, Thesis: The Multi-Media Approach to Content: A Teaching Unit. 1974.

yer, Verlene Carol, Thesis: A Self-Instructional Teaching Unit: The Mechanics of Respiration. 1977.

Neon, Sharon, Thesis: A Comparative Study of the Psychomotor Skill of Baccalaurate Students Instructed by ...Autotutorial or Lecture Method. 1977.

iss, Carol H. Evaluation Research (Englewood Cliffs, NJ: Prentice Hall)

ldavsky, Aaron, The Art and Craft of Policy Analysis (Boston: Little, Brown and Company, 1979)

ny Training Manual TM 21-250 (Department of the Army)

e Army Lesson Plan and Lesson Plan Cut Sheet (Department of the Army, 1951)

uster Implementation Guide, Career Education Division, State Department of Education, State of oregon

urse Content Guide Portland Community College (Gwenn Danielson, Instructor) 
irgency Care of the Sick and Injured, American Academy of Orthopedic Surgeons, 1971.

iluation Techniques, V.E: 9.00I, Portland Community College.

cst Aid Requirements Effective January 1, 1979, Portland State University School of Education Bulletin, 1979.

I Living Bible, (London, England: House Publishers, Ltd. , 1973)

zupational Cluster Guide, Oregon State Board of Education, Salem, Oregon. zupations Cluster Program Assessment Instrument, Instructional Services Division, State Department of Education, Salem, Oregon.

urse Description, Standard First Aid, HE *252, Portland Community College, 1979. 
$\underline{A} \underline{P} \underline{P} \underline{E} \underline{N} \underline{D} I \underline{X}$ 


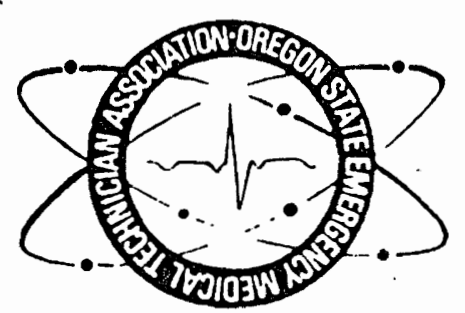

\section{in State Emergency Medical Technician Association}

EMT:

ave come to a crossroad in Oregon's Emergency Medical Services Program. he President of the Oregon State Ėmergency Medical Technician Association MTA), I have several concerns and need the input of all the EMTs (assoion members as well as non-members) to help make some important decisions, blish policies, and take an active position on key issues confronting EMT. Therefore, I am requesting that you complete the enclosed survey. abulate the following answers, please complete the questionnaire and m to: OSEMTA

$$
\begin{aligned}
& \text { P.0. Box } 3791 \\
& \text { Portland, OR } 97208
\end{aligned}
$$

'ebruary $12,1979$.

is an opportunfty to voice your concerns and questions regarding the ire direction of emergency medical care, training, standards, etc。

.11 take this opportunity to thank yuu in advance for your prompt ation in answering the enclosed questionnaire. :erely,.

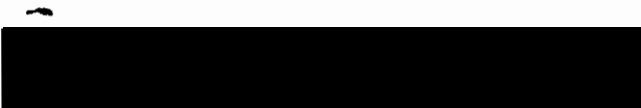

\section{lavid Dickson, President}

ITA

$\mathrm{dh}$

osure 
NOTE: On all "rank by priority" questions, 1 is the highest, 2 the next highest, etc. Additional space for answering question provided on last page.

1) Who should provide and conduct EMT certification courses in the State (rank by priority)?

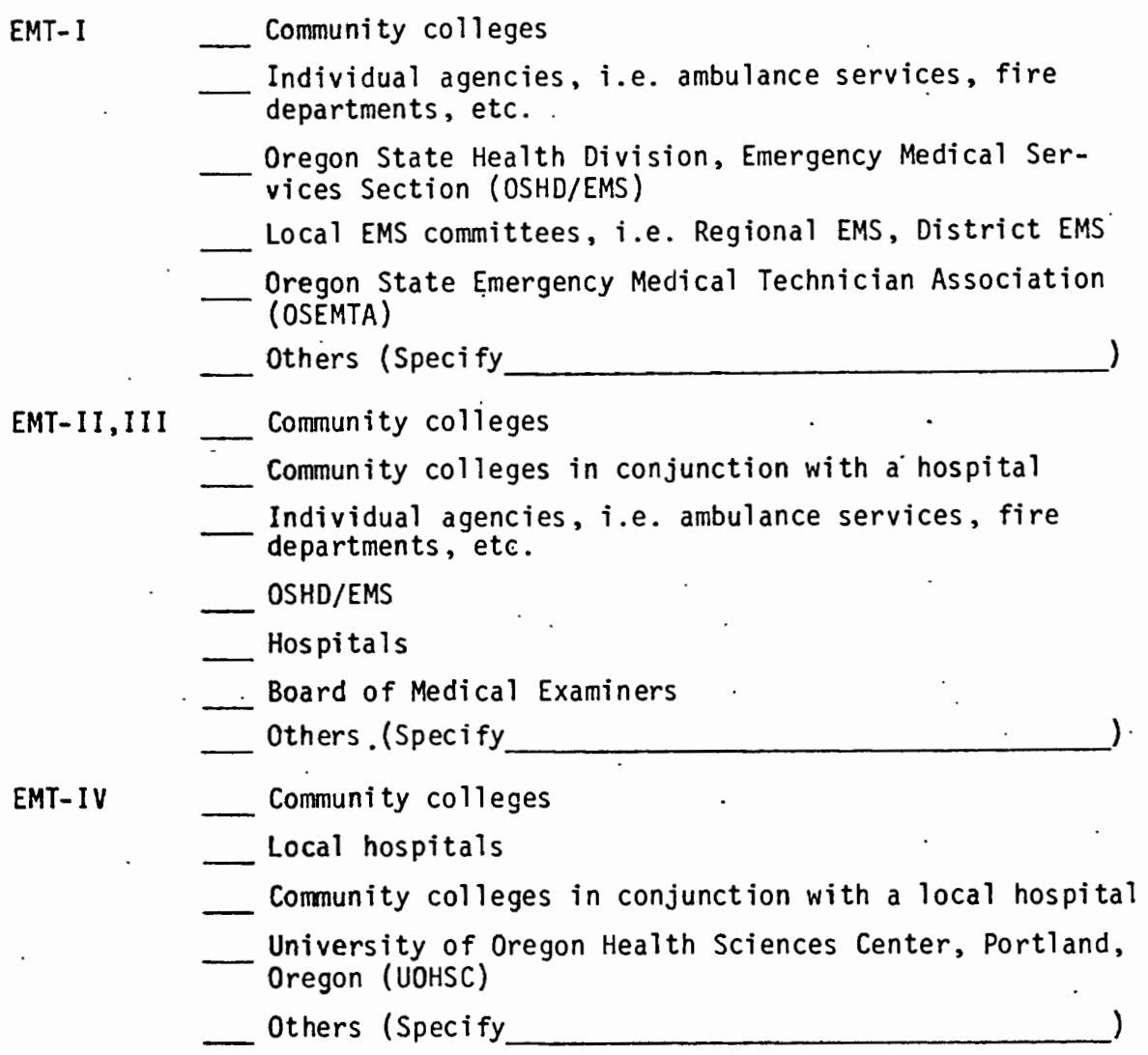

2) To insure standardized EMT-1 training, should there be State certified:

a) EMT-I instructors? __ Yes _ No

IF YES, of the following list of individuals presently used to teach EMT-I classes, who should be certified?

All MDs or DOS

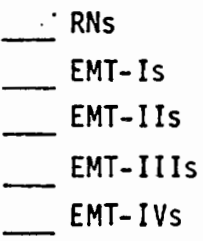

IF YES, who should provide the training for the instructors (rank by priority)?

OSEMTA, Instructors Division _ Community colleges
Other (Specify

A11 MDs and DOs except emergency EMT-Is

department physicians

others not included above

(specify

EMT-IIIS

EMT-IVS

Who should certify the instructor?

_ OSEMTA, Instructors Division Community colleges Other (Specify OSHD/EMS 
b) Should there be State certified EMT-I course coordinators (the coordinator would be responsible for scheduling classes, instructors, and tests; administering tests; handling paperwork, etc.)?

Yes No

IF YES, who should provide the certification for the coordinator?

_ Community colleges

Other (Specify

3) At present, OSHD/EMS provides the final written EMT-I exam. (Note: Currently, the OSHD/EMS Section is not required by law to provide or conduct the final written and practical exam.)

a) Who should provide written and practical final certifying exams (rank by priority)?

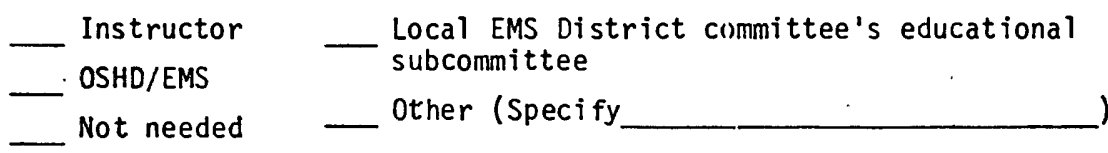

b) Who should conduct written and practical exains (rank by priority)?

Instructor
OSHD/EMS
Not needed

4) Currently, EMT-I continuing education standards are set by the OSHD/EMS and EMT-II, III, and IV standards are set by the Board of Medical Examiners. Who should set the continuing education standard for the EMT (check one)?

_ OSHD/EMS

Board of Medical Examiners

- Joint responsibility of OSHD/EMS and Board of Medical Examiners (existing policy)

Local EMS District committee's education subcomittee

OSEMTA

Other (Explain)

5) Currently, the law requires EMT-Is to complete 20 hours of continuing education every two years. Which of the following would you find to be most effective in maintaining basic skills (check one)?

No change - 20 hours continuing education

Pass a written and practical exam instead of 20 hours continuing education

Both - Complete 20 hours and pass a written and practical exam Less hours How many? More hours How many?

No continuing education requirements

other (Explain)

6) If your answer in Question 5 included testing,

Who should administer the exam?

Who should write the exam?

How often should the EMT be tested? 
7) Currently, the Board of Medical Examiners requires: a) EMT-IIs, 30 hours: b) EMT-IIIs, 40 hours; and c) EMT-IVs, 168 hours of continuing education for recertification.

Are these hours adequate?
a) EMT-II
- Yes<smiles>C1CCCCC1</smiles>
b) EMT-III
_ Yes
No (IF NO, how many hours?
c) EMT-IV
No (IF NO, how many hours?
No (IF NO, how many hours?

8) Currently, there is no required practical exam required in the EMT-II certification exam. Should there be a final practical certification exam for EMT-IIs?

Yes $\quad$ No

9). Should the practical exam include (check all that apply):
I.V. techniques _ MAST garment Intubation Oral nasal pharangel __ Esophagel airway
Other Specify

10) Currentiy, the curriculum for EMT-IIs is a revised OSHD developed course. Should the EMT-II curriculum be changed to coincide with the recommended national standards; D.O.T. course; ModuTe I - The EMT, His Role, Responsibilities and Training; Module 2 - Human Systems and Patient Assessment; Module 3.- Intravenous Therapy; and Module 5 - Respiratory System?

_ Yes No

11) In which manner would you prefer initial EMT-I training courses be funded (rank by priority)?

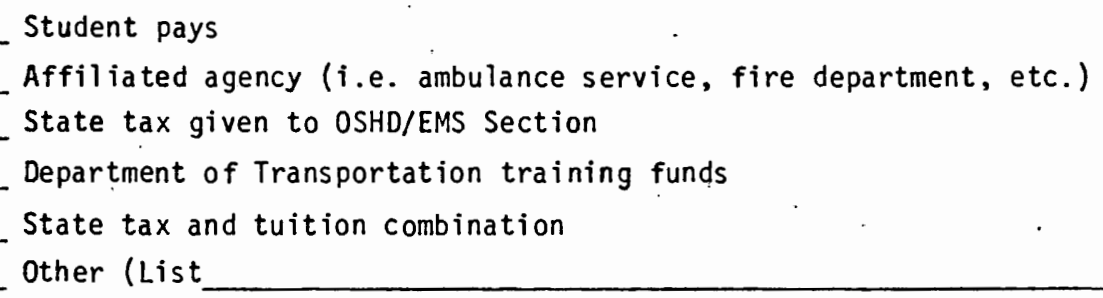

12) In which manner would you prefer initial EMT-II, III, and IV training courses be funded (rank by priority)?

Student pays

- Affiliated agency (i.e. ambulance service, fire department, etc.)

- State tax given to Board of Medical Examiners

- State tax given to OSHD/EMS Section

- Department of Transportation training funds

State tax and tuition combination

_ Other (List

13) Who should be financially responsible for the replacement of training equipment, i.e. films, video tapes, manikins, etc. (rank by priority)? Agency using equipment

- State general funds through OSHD/EMS

_ Students, fee for use Others (Name 
14) How should the replacement of operational equipment be funded, i.e. ambulances, defibrillators, MAST garments, extrication equipment, etc. (rank by priority)?

Fee for service

State general funds through OSHD/EMS

Loca 1 tax funds

Other (Specify

15) Which of the following activities should the OSHD/EMS be involved in (check all those that apply)?

Conduct EMT-I training and testing

Processing and monitoring State and federal EMS funds

Develop standards of care

Vehicle inspection (ground and air ambulance, rescue units, convalescent units, wheelchair coaches) and certification

EMT-I certification and recertification

EMT-II, III, IV certification and recertification

Others (List

16) How should OSHD/EMS Section administrative and planning activities be funded (list by priority)?

State general funds

Federal grant funds (if and when available) Note: Federal funds

cannot be used to implement and/or enforce State laws, i.e. ORS 485.500

- certification of EMTs and ambulances.

Local (county) tax funds

Others (List

17) Currently, certification for EMT-Is is under the OSHD/EMS Section and EMT-II, III, and IV is under the Board of Medical Examiners. Should all EMT certification be placed under one agency?

- Yes No

IF YES, rank by priority:

— OSHD/EMS

If No, check one:

Existing (no change) _ Others (List

18) Should all pre-hospital emergency care providers, i.e. ambulance services, fire departments, quick response units, adopt and use statewide standardized medical protocols (standing orders)?

$$
\text { - Yes _ No }
$$

IF NO, at what level (such as county-wide, district-wide, community-wide, etc.) would you like to see? Explain.

19) The Oregon State Emergency Medical Technician Association (OSEMTA) is a professional non-profit, tax deductible organization (not a union) addressing, among many items, education and standards of emergency care. Are you aware that this organization exists?

$$
\text { Yes' }
$$

IF YES, answer Question 20. IF NO, answer Question 21. 
20) As an association member, is OSEMTA serving your needs? Yes No

IF NO, what would you like to see OSEMTA involved with (check all that apply)?

More seminars

More involvement with legislative matters

Closer relationship with OSHD/EMS Section

Closer relationship with physician and nurses associations other 'List

21) What do you, as a non-member, see OSEMTA being involved with (check all that apply)?

Educational seminars

Involvement with legislative matters

Closer relationship with .OSHD/EMS Section Closer relationship with physician and nurses associations others (List

Please use the space below to expand any of the above answers or list any additional suggestions that you may have. 
TO ALL EDUCATION STUDENTS

First Aid Card Requirements Effective January 1, 1979

tain any certificate (basic or standard) or to renew any certificate after ry 1,1979 , you must possess a valid First Aid Card

ifst you in meeting this requirement the School of Health and Physical Education ie American Red Cross have arranged a 1 credit ( 8 hour) course to be offered three during Fall Term:
1. Saturday, October 14th
$8:(10 \mathrm{am}-5: 30 \mathrm{pm}$
2. Thursday, October 26th
Friday, October 27 th
$6: 00 \mathrm{pm}-10: 15 \mathrm{pm}$
$6: 00 \mathrm{pm}-10: 15 \mathrm{pm}$
3. Saturday, November 4th
$8: 00 \mathrm{am}-5: 30 \mathrm{pm}$

tion of this 8 hour experience will result in you obtaining a Red Cross MultiFirst Aid Card.

ration for the course will be limited to 45 for each session. You may register the first two weeks of Fall Term by adding the course:

HE199 (1 Credit) First Aid: Multi-Media

ration will be allowed up to the start of each session, however the enrollment e limited to 45 for each session. Cost will include text materials for the class.

K INFORMATION CAN BE OBTAINED BY CONTACTING THE SCHOOL OF HEALTH AND PHYSICAL TON - PHONE 229-440?

tion of this course WILL NOT be equivalent to the HE252 First Aid course. 
HE 252

iIII

Spring Term:

Required Text:
PORTLAID CORTUITYY COLLEGE

Standard First Afd

3 credit hours

Advonced First Aid ard Enemency Care, American llaticnal

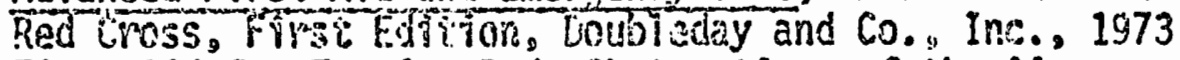
First Aid for Foreign Body Obstructions of the Airyay, Anepican Ilatronal Rec Cross ior.

Cardiopuimonary Resuscjtation, Aurerican llatronal Red Cross, $197 \%$.

Reconmended Reading: Emergency Care and Transportation of the Sfok and Injumed,

Course Requipenents: $570 \%$ or greiter on 3 of 4 written examinations

"sacisfactory perfomance on a practica" axam

wcheck-off of certain skills with instructor (e.a., bandagivg, splinting, CPR, iransportation)

*participating in situational exercises

tclass attendance (no more than three absences)

DATE

liarch 23

April 2

4

9

11

16

18

23

25

30

llay 2

7

9

14

16

21

23

28

30
SUBJECT

Introdiction to First Ald

Respiratory Enargene?es

Cardtac Arrest

CPR

Sudden Illness

Hounds/Shock

Bandzging

ExAPI

Spectific Injuries

Bone \& joint infuries

RescuefTransfer

Splinsing/Transfer

Splining/Transfer

EXAl (proctica])

EXAl! (writiten)

Burns \& Heat Exposure

Cold Exposurejts ofsoning

lievoryal Dáy

Enorgency Childbirth

EXAN WEEK
TEXT ASSIGHIIEIIT

Chapiser 1

Chapter 5, 6

Bookiets

Chapter 15

Chapier 24

Chapter 13

Chapter 17
Chapter 2, 4 :

Chapter 3
Chapter 9

Chapser 11, 12 
it/e

GUIDELINE FOR COURSE CONTENT GUIDE

\begin{tabular}{|c|c|}
\hline$\therefore$ & \begin{tabular}{l|l|l|l|l|} 
Approved by & Page & Date & \\
Barry Noonan COBY & 1 of 3 & Rev. & $11-24-75$ &
\end{tabular} \\
\hline (1) & $\begin{array}{l}\text { The statement of purpose sets forth the course's ov } \\
\text { These goal statements may be broad and general. } \\
\text { The introduction should include the following: } \\
\text { a. Brief catalog type overview of course conten } \\
\text { b. Number of course credits } \\
\text { c. Number of class hours per week } \\
\text { d. Number of lab hours per week } \\
\text { e. Certificate and/or degree requirements met } \\
\text { f. Transferability or non-transferability of cr } \\
\text { g. Approximal institutions. } \\
\text { furnish. } \\
\text { h. If the course is designed for entry level ef } \\
\text { job upgrading, then a statement should be ma } \\
\text { kind(s) of job(s) for which the course(s) pr }\end{array}$ \\
\hline
\end{tabular}

II. COMMENTS ON COURSE

ACTIVITIES AND DESIGN

V. PREREQUISITE KNOWLEDGE AND SKILLS
A paragraph or so which motivates the student to take the course. Also, comments which tell the reader how the course is to be conducted (e.g., lecture/response, several large group lectures and many small group sessions, several large group sessions with instructor plus selected small group snythes is seminars, reference to field trips, etc.). If there is more than one basic presentation format, then the alternative(s) may be listed or the reader should be told who to see for information.

Statement which includes one or more of the following:

a. Title and course number of any prerequisite course(s).

b. List of any skills and knowledge which are necessary for entry to the course (e.g., math skills, reading ability, etc.).

c. Statement regarding physical factors such as an ability to lift heavy objects, color vision, good vision, etc.

d. Statement of any assumptions which the instructor or depart ment makes regarding student's reason for taking the course (e.g., an introductory science course may be designed for students who want a survey course rather than an introductory course which leads into several additional courses.)

e. : Statement that there are no prerequisites. 
GUIDELINE FOR COURSE CONTENT GUIDE

\begin{tabular}{|l|l|l|l|l|l}
\hline ype & Approved by & Page & Date \\
\hline
\end{tabular}

V. EVALUATION

The evaluation section should include statements regarding the following:

a. Indicate type(s) of test(s) used or other methods for determining subject matter competencies.

b. Grading policy (i.e., attendance, written exams, projects, etc.)

If there is no set departmental position regarding evaluation procedures to be used in the course, then enter a statement suggesting that "Evaluation procedures will be discussed during the first class meeting."

VI COURSE

The course outline contains a listing of the major topics and subtopics of instruction. The two digit system shown below is recommended. The course outline is a topical outline and is not necesscorily the sequence in which the material will be presented.

Here is an example of an outl ine from "BASIC SPEECH COMMUNICATIONS" ( $T$ Sp 100) which is a college transfer speech class:

\subsection{SPEECH-COMMUNICATION PERSPECTIVES}

1.1 Overview: History of Rhetoric

1.2 Contemporary Communication Theory: Status

2.0 INTRAPERSONAL COMMUNICATION

2.1 Selective Exposure, Perception, Retention

2.2 Language and Reality

2.3 Reducing Intrapersonal Communication Barriers

3.0 INTERPERSONAL COMMUNICATION

3.1. Interpersonal Communication Components

3.2 Self-Concept, Roles, Behavior

3.3 


\section{Manual for Improvement of Instruction}

Porlland Community College

it/e

GUIDELINE FOR COURSE CONTENT GUIDE

\begin{tabular}{l|l|l|l|l|l}
\hline pe Guideline & $\begin{array}{l}\text { Approved by } \\
\text { Barry Noonan }\end{array}$ aßon & 3 of 3 & Rev. 11-24-75 & Page \\
\hline
\end{tabular}

I. INSTRUCTIONAL GOALS AND

DEFINED

OUTCOMES

INSTRUCTIONAL GOALS are more general statements of learning outcomes than what is referred to in this section as DEFINED OUTCOMES. For each subtopic listed in the course outline, there is usually at least one instructional goail.

DEFINED OUTCOMES state the knowledge and skills which the student should possess upon completion of a given curriculum. When formulating the DEFINED OUTCOMES, one should carefully consider what the student is to gain from the learning experience.

Here is an example of an instructional goal and several defined outcomes:

\subsection{SPEECH-COMMUNICATION PERSPECTIVES}

1.1.0 Overview: History of Rhetoric

Instructional Goal:

INSTRUCTIONAL GOAL

DEFINED OUTCOMES

PCC TYPISTS PLEASE NOTE
Be aware of the tradition of rhetoric from approximately 500.B.C. to the present, including major shifts in emphasis: Aristotelian and Sophist influence, Middle Ages, Eighteenth and Nineteenth Centuries, and current research trends.

\section{Student Wi11:}

1.1.1 Discuss the earty origin of rhetorical study. including reasons for development, major figures, and major ideas.

1.1.2 Discuss major contributions to, and changes in, rhetorical tradition during the period from 500 B.C. - 300 A.D., Middle Ages, Eighteenth Twentieth Century.

It is recommended that:

1. Use Form $P-31-3$ for ODD numbered pages ( $1,3,5$, etc.)

2. Use Form P-3I-3a for EVEN numbered pages $(2,4,6$, etc.)

These forms are available from the Planning Department. 
1 Instructor

Organization

Date prosented

\section{$\underline{I} \underline{\underline{S}} \underline{\mathrm{O}} \mathbb{N} \quad \underline{P} \underline{\mathrm{A}} \underline{\mathrm{N}}$}

LESSON TITIE:

TYPE\&

TIME AIIOT TED:

CIASSES PRESENTED TO:

MATERIALS FOR STUDENT USE:

INSTRUCTOR PERSONNEL.

IHSTRUCTIONAI TRAINING AIDS:

REFERENCES:

STUDY ASSIGNMENTS:

STUDENT UNIFORM AND EQUIPMENT:

TROOP. REQUIREIIENTS:

TRANSPORTATION REQUIREMENTS:

(On additional sheets, make a complete outline covering material to be presented and nethod by which this will be done. The following basic, skeleton outline may be used as a guide, remembering that the bulk of the

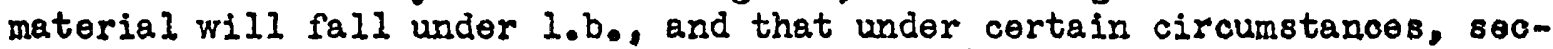
tions of the outline may be omitted entirely.)

1. Presentation

a. Introduction..

(1) Opening statement

(2) Objeotive of lesson

(3) Reasons and/or standards

b. Explanation and/or Demonstration

2. Application by class (if to be used in lesson)

3. Examination (if to be used in lesson)

4. Disoussion or critique

a. Questions from class to be cleared up

b. Summary of entire lesson

c. Closing statement 


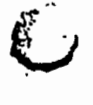

OREGON MILITARY DISTRICT

50

MATHODS OF INSTRUCTION

VANCOUVER BARRACKS

- Vanoouver, liashington

LESSON PLAN CUT SHEET

Name

Points Cut

NORE, The notations on your lesson plan have the meanings indicated below. For example, if the number " 4 " (in red) is on your lesson plan, it means that at the puint indicated by the number "4" there was need for support of the topics used (see 4 below).

Notations in parentheses below refer to paragraphs in TECHIQUES OF MILITARY INSTRUCTION where you can find the explanation of defiolencios.

1. The heading of this plan doos not includis all necessary information. (Par 1, page 48)

2. The introduction does not provide for such essential elements as the objective of the lesson or reasone for learning. (Pax la, pa.ge 48)

3. In the organization of your subjeot matter, there are too many main points. (Par 2b, page 52)

4. The mein points are not adequately supported by sub-topics. (Par 2c, page 52)

5. The outline form used in this plan does not provide for propor designation of topics. (Par 2a, page 51)

6. Plan does not indioate where charts or other training aids are to be used. (Par $1 b(2)$, page 49)

7. Losson plan should include suggestions.as to the teaching procedures used in the presentation of the lesson. Use NOTE: QUESTION: etc. (Par 1b(2), page 49)

8. Final summary is not proporly providod for. (Par 4b, page 5I)

9: Provido for closing statemont. (Far 4c, page 5I).

10. Plan is not readily usebio because of the quality of legibility and neatness.

11. Toples and subtopics should bo at least two in number if they are to be designated in the outline. (Par 2d, page 53)

12. Strive for parallel phrasing in coordinate parts of the outline. (Par 2f, page 54) 